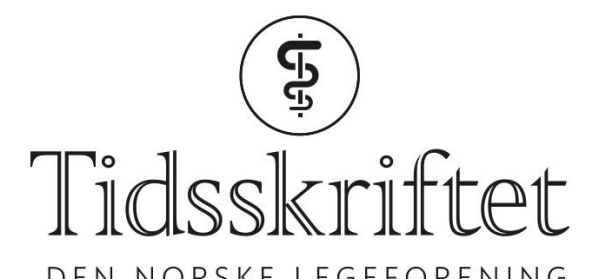

DEN NORSKE LEGEFORENING

\title{
Effekt av arbeidsrettet rehabilitering på sykefravær
}

DOKTORAVHANDLINGER

LENE AASDAHL

E-post: lene.aasdahl@ntnu.no

For sykmeldte med muskel- og skjelettplager eller lettere psykiske lidelser hadde ikke døgnbasert arbeidsrettet rehabilitering større effekt på verken sykefravær eller helse enn et enklere poliklinisk tilbud.

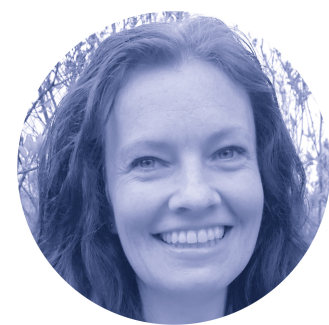

Muskel- og skjelettplager og lettere psykiske plager utgjør til sammen ca. 6o\% av sykefraværet i Norge. Til tross for at døgnbasert arbeidsrettet rehabilitering har vært tilbudt i Norge i over 30 år, er effekten av disse programmene aldri blitt undersøkt med en randomisert studiedesign.

Vi utførte en randomisert, klinisk studie hvor vi sammenlignet effekten av et døgnbasert arbeidsrettet rehabiliteringsprogram som varte i $4+4$ dager med et mindre omfattende poliklinisk behandlingstilbud, bestående hovedsakelig av kognitiv atferdsterapi. Aktuelle deltagere var personer mellom 18 og 60 år som var sykmeldt (minst 50\%) mellom åtte uker og 12 måneder med muskel- og skjelettplager og/eller lettere psykiske lidelser.

Hovedendepunkt i studien var sykefravær basert på Nav-data. Helsevariabler ble målt med spørreskjema på flere tidspunkter frem til 12 måneder. Til sammen 168 personer ble inkludert i studien.

Det var ingen statistisk signifikant forskjell mellom programmene i antall sykefraværsdager i løpet av 12 måneders oppfølging eller antall som oppnådde tilbakeføring til jobb og hvor lang tid det tok. Det var heller ingen forskjell mellom programmene på somatisk eller psykisk helse.

Studien viser at det ikke finnes støtte for at et $4+4$ dager døgnbasert arbeidsrettet rehabiliteringsprogram er bedre enn et enklere poliklinisk program, og at dette programmet derfor ikke bør implementeres i ordinær rehabilitering. 


\section{Disputas}

Lene Aasdahl disputerte for ph.d.-graden ved Norges teknisk-naturvitenskapelige universitet 9. mars 2017. Tittelen på avhandlingen er Occupational rehabilitation and readiness for return to work in individuals with musculoskeletal complaints and mental health disorders: A randomized clinical trial.

Publisert: 4. september 2017. Tidsskr Nor Legeforen. DOI: 10.4045/tidsskr.17.0468

(C) Tidsskrift for Den norske legeforening 2020. Lastet ned fra tidsskriftet.no 